NBER WORKING PAPER SERIES

\title{
WHY WAS EUROPE LEFT AT THE STATION WHEN AMERICA'S PRODUCTIVITY LOCOMOTIVE DEPARTED?
}

\author{
Robert J. Gordon \\ Working Paper 10661 \\ http://www.nber.org/papers/w10661 \\ NATIONAL BUREAU OF ECONOMIC RESEARCH \\ 1050 Massachusetts Avenue \\ Cambridge, MA 02138 \\ August 2004
}

This research has been supported in part by the National Science Foundation. I am grateful to Bart van Ark and Robert McGuckin for the data underlying Tables 2 and 3, and to them, and Martin N. Baily, Jean-Paul Fitoussi, and Edmund S. Phelps for many discussions of the central ideas. The views expressed herein are those of the author(s) and not necessarily those of the National Bureau of Economic Research.

(C2004 by Robert J. Gordon. All rights reserved. Short sections of text, not to exceed two paragraphs, may be quoted without explicit permission provided that full credit, including (C) notice, is given to the source. 
Why was Europe Left at the Station When America's Productivity Locomotive Departed?

Robert J. Gordon

NBER Working Paper No. 10661

August 2004

JEL No. N0, N10, O30

\section{ABSTRACT}

After fifty years of catching up to the United States level of productivity, since 1995 Europe has been falling behind. The growth rate in output per hour over 1995-2003 in Europe was just half that in the United States, and this annual growth shortfall caused the level of European productivity to fall back from 94 percent of the United States level to 85 percent. Fully one-fifth of the European catch-up (from 44 to 94 percent) over the previous half-century has been lost over the period since 1995 .

Disaggregated studies of industrial sectors suggest that the main difference between Europe and the United States is in ICT-using industries like wholesale and retail trade and in securities trading. The contrast in retailing calls attention to regulatory barriers and land-use regulations in Europe that inhibit the development of the big box retailing formats that have created many of the productivity gains in the United States. For many decades, the United States and Europe have gone in opposite directions in the public policies relevant for metropolitan growth. The United States has promoted highly dispersed lowdensity metropolitan areas through its policies of building intra-urban highways, starving public transit, providing tax subsidies to home ownership, and allowing local governments to maintain low density by maintaining minimum residential lot sizes. Europeans have chosen different policies that encourage highdensity residential living and retail precincts in the central city while inhibiting the exploitation of greenfield suburban and exurban sites suitable for modern big box retail developments.

The middle part of the paper draws on recent writing by Phelps: economic dynamism is promoted by policies that promote competition and flexible equity finance and is retarded by corporatist institutions designed to protect incumbent producers and inhibit new entry. European cultural attributes inhibit the development of ambition and independence by teenagers and young adults, in contrast to their encouragement in the United States. While competition, corporatism, and culture may help to explain the differing transatlantic evolution of productivity growth, they reveal institutional flaws in both continents that are inbred and likely to persist.

The final section of the paper identifies the roots of the favorable environment for innovation in the United States compared to Europe. Elements include an openly competitive system of private and public universities, government subsidies to universities through peer-reviewed research grants rather than unconditional subsidies for free undergraduate tuition, the world dominance of United States business schools and management consulting firms, strong United States patent protection, a flexible financial infrastructure making available venture capital finance to promising innovations, the benefits of a common language and free internal migration, and a welcoming environment for highly-skilled immigrants.

Robert J. Gordon

Department of Economics

Northwestern University

Evanston, IL 60208-2600

and NBER 


\section{Introduction}

After a half century following World War II of catching up to the level of U. S. productivity, since 1995 Europe has experienced a productivity growth slowdown while the United States has experienced a marked acceleration. As a result, just in the past eight years, Europe has already lost about one-fifth of its previous 1950-95 gain in output per hour relative to the United States. Starting from 71 percent of the U.S. level of productivity in 1870, Europe fell back to 44 percent in 1950, caught up to 94 percent in 1995, and has now fallen back to 85 percent. What were the causes of this stunning setback?

This paper argues that the discussion of policy reform in Europe has been too narrowly focussed on the deregulation of product and labor markets. A broader set of social choices matters for productivity, and some of these differences between the U.S. and Europe may be irreversible. Much of the surprising acceleration of U. S. productivity growth since 1995 originates in the trade sector, particularly retail trade, and goes far beyond the use of information and communication technology (ICT). The retail sector in the U. S. has been revolutionized by the "big box" format epitomized by Wal-Mart, and perhaps the most important factor of production in making this format possible is a large plot of virgin land which is much more widely available in the sprawling American metropolitan areas than in tightly regulated European environment of land-use planning and protection of old central city retail zones. The American explosion of productivity growth in retailing calls attention to basic life-style choices that constitute yet another form of "American Exceptionalism." While the American form of metropolitan organization may promote productivity growth, Europeans are rightly skeptical of unmeasured costs of low urban density in America as promoted by explicit government policies. Europeans decry side-effects of the American system that may promote productivity without creating consumer welfare, including excess energy use, pollution, and time spent in traffic congestion. 
A second set of major differences originates in what could be called "European exceptionalism." As Phelps has argued, European growth is still retarded by corporatist institutions which are designed to protect incumbent producers and inhibit new entry. European cultural attitudes inhibit the development of ambition and independence of teenagers and young adults, who are cradled in subsides such as free tuition for higher education while American teenagers are expected to get out into the marketplace, work, and contribute real money to their own college education. The differing behavior of productivity growth since 1995 helps to call attention to differences between Europe and the U. S. which have long been present but seemed unimportant during the five decades prior to 1995 when Europe was rapidly catching up to the American level of productivity.

A third issue raised by the U.S. post-1995 productivity revival has been an explosion of innovation in the production and use of ICT. The past decade has witnessed a growing concentration of innovative activity in the United States, not only in computer hardware and software, but also in pharmaceuticals and biotech research. The sources of this innovative advantage call attention to European shortcomings that cannot be easily cured by deregulation. These include the continuing U. S. advantage of a unified market unincumbered by differences in customs, language, or electric plugs; the competitive U. S. system of private and public universities; the system of peer review that guides U.S. government support of research; well-enforced patent protection; a dynamic capital market able to fund promising start-ups; and the welcome extended by the United States to foreign graduate students in all fields and especially to highly skilled immigrant engineers.

It is important at the outset not only to set out the topic issues discussed in this paper, but also those that are outside its purview. We have nothing to say here about the well-trodden issues in the functioning of the European labor market, deregulation of labor markets past, present, or future, and specific issues involving product market regulations, 
e.g. shop-closing hours. Also, while this paper highlights life-style and cultural differences, it does not attempt a comprehensive comparison of standards of living, and its several dimensions of praise for the American system should not be interpreted as an endorsement for well-known failures such as the lack of universal government-financed health care in the United States. ${ }^{1}$

The paper begins with basic data on productivity growth in Europe and the United States over selected intervals since 1870 and displays the relative level of European productivity, falling behind until 1950, catching up until 1995, and then falling behind since then. Data on differences at the sectoral level are then displayed, highlighting the role in the U. S. revival of ICT-using industries, especially retailing. The paper then continues with a comparison of the retailing environment in the U. S. vs. Europe, followed by attention to broader cultural issues. It concludes with a multi-part comparison of the stimuli and barriers to technical change and innovation on the two sides of the Atlantic.

\section{Data on Trans-Atlantic Productivity Differences: Growth Rates and Levels}

The long history of productivity growth and levels is displayed in Table 1. The data from 1870 to 1990 come from Maddison (2001) and refer to the total economy, that is, real GDP per hour. These data are updated for 1990-2003 with OECD data on the private economy. While productivity growth in the private economy is usually slightly faster than in the total economy, this is true both in the U. S. and in Europe, and so the break in coverage at 1990 should not affect our main point of concern, that is, transatlantic

1. A more balanced view that attempts to quantify an overstatement of U. S. welfare relative to Europe is provided in Gordon (2002). 
differences in growth rates and their implications for relative levels. ${ }^{2}$

The left section of Table 1 shows average annual percentage growth rates of productivity in the U. S., Europe and the U. S. - Europe difference, for selected intervals since 1870. The familiar story is that Europe fell behind from 1870 to 1950, then caught up after 1950. Less familiar is the extent to which Europe has fallen behind again after 1995. As shown in the right section of Table 1, Europe had almost closed the gap in productivity levels by 1995, but its slow growth since then has caused its relative productivity level to slip back from 94 to 85 percent, eroding 9 points of its 50 point catch-up between 1950 and 1995.

A closer look at the divergence is provided by Table 2, which contrasts the 1990-95 period with 1995-2003 and provides a uniform treatment of the total economy based on a new Conference Board pamphlet by McGuckin-van Ark (2004). The initial European slowdown evident in data for 1995-2000 worsened with data for 2000-2003, whereas the U. S. sustained its productivity growth revival. We should note that the 1995-2003 difference between U.S. and European productivity growth is less than in Table 1, and so the extent of European retrogression depends on whether we use the post-1990 data on the private economy, as in Table 1, or on the total economy, as in Table 2. Given the well-known difficulties in measuring productivity in the government and non-profit sector, we prefer to emphasize the greater difference shown in Table $1 .^{3}$

2. The Maddison data refer to 12 countries weighted by relative GDP; these are the 15 members of the EU minus Greece, Portugal, and Spain. The post-1990 OECD data refer to all 15 EU members. While the Maddison are available through 1998, he provides no intermediate data between 1990 and 1998, and we choose 1995 as a preferable break date which highlights the starting point of the transatlantic productivity growth divergence.

3. The less impressive U. S. performance in Table 2 is due to the use by McGuckin and van Ark (2004) of household employment figures to calculate economy-wide productivity, unlike Table 1 where the OECD follows U. S. practice by calculating private-sector productivity based on the slower-growing payroll employment data. For a discussion of this discrepancy, see Gordon (2003, p. 258-61 and the sources cited 
The right-hand column of Table 2 displays the change in output, hours, and output per hour between 1990-95 and 1995-2003. The post-1995 acceleration in output growth was slightly less in Europe than in the U. S., 0.6 vs. 0.9 percentage points, respectively. Most of the literature on the failure of Europe to achieve a post-1995 productivity growth acceleration treats Europe as overregulated and stuck in the mud. On the contrary Europe's performance in hours of work was the diametric opposite of the U.S., accelerating by almost two percentage points compared to pre-1995, whereas there was no change in hours growth in the U. S. As a result, the productivity change between 1990-95 and 19952003 was the mirror image of the hours change, with an acceleration of almost one percent per annum for the U. S. and a deceleration of more than one percent for Europe.

\section{Understanding Europe: Distinguishing the Stars from the Basket Cases}

If the decomposition of growth sources is a booming academic industry on the west side of the Atlantic, laments about Europe's performance are the corresponding concern of academics on the east side of the Atlantic. While the U.S. enjoyed a productivity growth revival after 1995, as we have seen in Tables 1 and 2, a growth deceleration occurred in numerous European countries as well as in the European Union as a whole. This EuropeU. S. contrast seems to fly in the face of the widespread evidence (Oliner-Sichel, 2000, 2002; Jorgenson-Stiroh 2000) that investment in information and communications technology (ICT) was the basic source of the U. S. achievement. How could ICT be the main source of the U. S. growth revival, while Europe fell behind? Business firms, not to mention university professors, use the same PCs and Microsoft software everywhere in Europe, and Europe is widely acknowledged to be ahead in the use of mobile telephones.

Part of the European puzzle is resolved when we recognize that heterogeneity

there). 
among European countries is more pronounced than the difference between the European Union and the U.S. Numerous studies have shown a relatively strong positive correlation between MFP growth and measures of ICT use, e.g., the ratio of ICT expenditure to GDP or the change in PC use per 100 inhabitants over the 1990s. In such comparisons, numerous countries achieve higher MFP growth rates than the U. S. over the 1990s, including Ireland, Finland, Sweden, Denmark, Norway, Canada, and Australia. Some, but not all, of these countries surpass the U.S. in PC use per household and/or in the share of ICT expenditure. What differs most between Europe and the U. S. is the low level of PC adoption and ICT expenditure in the "olive belt" ranging from Portugal and Spain on the west to Italy and Greece in the east. ${ }^{4}$ The contrast between the Nordic and olive-belt countries suggests irreverent comments about how Scandinavians in their dark winters find PCs more appealing than do olive-belt residents cavorting on their sunny beaches.

Contrasts within Europe also suggest that perhaps we could try to disaggregate the U. S. to provide a more appropriate comparison with Europe. Silicon Valley could be compared to Ireland and Finland, New England could be compared to Denmark and Sweden, Texas to Australia, and the midwestern heartland to France and Germany. What stands out in this suggestion is the absence of any U. S. equivalent for the European olivebelt countries. Political borders are a product of history, and perhaps the U.S. would look more like Europe, which includes the olive belt, if we were to aggregate U. S. data with those for the tequila belt, i.e., Mexico.

\section{The Industry Decomposition of the Europe-U. S. Difference}

A comprehensive recent study by O'Mahoney and van Ark (2003) provides a few answers at a more formal level. As shown in Table 3, they support the widespread

\footnotetext{
4. Scatter plots supporting these correlations between MFP growth and computer intensity are presented in Bartelsman et al. (2002, Figures 8 and 9).
} 
impression that America accelerated while Europe fell behind. The top line in Table 3 shows that U. S. productivity growth accelerated by 1.1 percent in the late 1990s while European growth decelerated by 0.6 percent. An initial caveat is that Europe looks much better when the entire decade of the 1990s is aggregated into a single 1990-2001 period; European productivity growth averages out to 2.0 percent per year, considerably higher than U. S. growth of 1.6 percent per year. It is important to remember the different terminal dates in Tables 1 and 2 vs. Table 3. The first two tables end in 2003 and incorporate explosive U. S. productivity growth in 2001-03, whereas Table 3 ends in 2001 and is influenced by slow U. S. growth during its 2001 recession.

The O'Mahoney and van Ark study allows us to trace the location of productivity growth accelerations and decelerations to particular industrial sectors, divided into ICTproducing, ICT-using, and non-ICT industries. There has been no productivity revival in U. S. industries that are classified as neither ICT-producing nor ICT-using, and this is confirmed on the bottom line of Table 3 for the U.S. These industries are also the core of the European problem, exhibiting a deceleration in the late 1990s slightly greater than for the European economy as a whole. In ICT-producing industries there was an acceleration after 1995 of 1.9 percent per year in the U. S. and a similar 1.6 percent per year in Europe, but the U.S. started from a higher base. The core of the U.S. success story, and the source of its difference from Europe, appears to have been in ICT-using industries, i.e., retail, wholesale, and securities trading industries.

A separate analysis by van Ark et al. (2003, Figure 2a) shows that literally all of the productivity growth differential of the U. S. over Europe in the late 1990s came from these three industries, with retail contributing about 55 percent of the differential, wholesale 24 percent, and securities trade 20 percent. The remaining industries had small positive or negative differentials, netting out to zero. As might have been expected, the U. S.-Europe 
differential was negative in telecom services, reflecting U. S. backwardness in mobile phones.

\section{The Retailing Phenomenon}

We know thatU.S. productivity growth accelerated after 1995, and we can speculate about the aspects of ICT innovation that helped this acceleration to occur. But the simultaneous acceleration in productivity growth and in ICT investment as a share of GDP amounts, at least in part, to circumstantial evidence. Questions can be raised about the link between ICT innovation and the productivity revival, given evidence of a further acceleration of productivity growth in the years after 2000, a period when ICT investment collapsed. Other aspects of innovation beyond ICT may be as important as ICT in explaining the outstanding productivity performance since 1995 of the U. S. retail trade sector.

This performance did not occur evenly across the board in retailing but rather was concentrated in "large stores offering a wide array of goods accompanied by low prices and relatively high use of self-service systems" (Sieling et al. 2001, p. 10). A complementary finding by Foster et al. (2002) based on a study of a large set of individual retail establishments shows that all of retail productivity growth (not just the revival but the entire measured amount of productivity growth over the decade of the 1990s) can be 
attributed to more productive entering establishments which displaced much less productive existing establishments. The average establishment that continued in business exhibited zero productivity growth, and this despite the massive investment of the retail industry in ICT equipment that presumably went to both old and new establishments. In the Foster results, productivity growth reflects the greater efficiency of newly opened stores, and the Sieling comment implies that most of these highly efficient new stores were large discount operations, the proverbial "big boxes" like Wal-Mart, Home Depot, Best Buy, Circuit City, and new large supermarkets.

The Sieling and Foster findings seem to conflict with the Oliner-Sichel $(2000,2002)$ finding that, at least for the period through 1999, all of the productivity revival in retailing was achieved by purchasing new computers, software, and communications equipment. ${ }^{5}$ All retailers, whether new estabilishments of the 1990s or older establishments of the 1980s or prior decades, have adopted ICT technology. Bar-code readers have become universal in new and old stores. It is likely that the productivity revival in retailing associated with newly built "big box" stores involves something beyond the use of computers, including large size, economies of scale, efficient design to allow large-volume unloading from delivery trucks, stacking of merchandise on tall racks with fork-lift trucks, and large-scale 
purchases taken by customers to vehicles in adjacent parking lots.

As we have seen, the van Ark et al. (2002) results identify the retail sector as a major factor explaining Europe's poor performance in the late 1990s. Just as the U. S. retailing sector has achieved efficiency gains for reasons not directly related to computers, including physical investments in a new type of "big box" organization, so we can suggest in parallel that Europe has fallen back because European firms are much less free to develop the "big box" retail formats. ${ }^{6}$ Impediments include land use regulations that prevent the carving out of new "greenfield" sites for "big box" stores in suburban and exurban locations, shopclosing regulations that restrict the revenue potential of new investments, congestion in central-city locations that are near the nodes of Europe's extensive urban public transit systems, and restrictive labor rules that limit flexibility in organizing the workplace and make it expensive to hire and fire workers with the near-total freedom to which U.S. firms are accustomed.

A complementary interpretation is provided in a cross-country study of productivity differences in the service sector by the McKinsey Global Institute (1992). Their set of policy recommendations (Chapter 2-D, pp. 13-14) seem as relevant today as when written a decade ago and echo the previous paragraph by pointing to impediments to the

\footnotetext{
6. Any generalizations here about "Europe" must be qualified by differences across countries. The Germans until recently were notorious for restrictive shop-closing hours, while the French firm Carrefour and the Swedish firm Ikea are innovators in "big box" retailing formats.
} 
development of modern retailing in some but not all European countries. European policymakers have adopted a set of policies that encourage high density and a concentration of retailing activity in the central city. The development of modern "big box" retailing formats has been hindered by these policies and the resulting high cost of real estate and the complex and precarious process of obtaining planning approval for large plots of land.

An issue identified by McKinsey is the role of resale price maintenance policies that in the U.S. assure new competitors that they will be able to attain the same access to suppliers at roughly the same prices as existing retailers. In contrast, in some European countries producers refuse to discount to new, high-volume, low-cost retailing formats in order to protect smaller high-cost merchants. In some European countries, regulations directly prohibit the entry of large-scale stores and/or limit store opening days and hours, thus preventing large stores from fully amortizing their investments.

A partial survey of other cross-country studies reveals a disappointing lack of specific conclusions at the level of the van Ark et al. and McKinsey studies. The typical study conducts a growth accounting exercise, concludes that Europe has lagged behind the U. S. in adopting ICT technology to a greater or lesser degree, does not trace differences in behavior to specific industries, and concludes with a general plea for unspecified structural reforms. Among the studies that fit this characterization are Colecchia and Schreyer (2001), 
Daveri (2002), Rhine-Westphalia Institute for Economic Research (2002), and Vijselaar and Albers (2002).

A final caution is in order. The superior performance of U. S. retailing in achieving rapid productivity growth may in part be due to a measurement procedure that allows quality improvements in manufacturing to spill over to the retail sector. Imagine a 2003 computer sold at the same price as a 1993 computer but containing four times the "quality," measured by a hedonic price regression that includes the computer's speed, memory, and additional attributes (presence of CD-DVD read-write capability, presence of USB ports, better speakers, etc). Then the 2003 computer represents four times the real output of the manufacturing sector and four times the real sales of the retail sector. If all that the retailing sector sold was computers, and if computer boxes sold per retail employee were constant, the U. S. methodology would register an annual productivity growth rate for retailing of 13.9 percent per year. While there has been substantial discussion of the role of hedonic price indexes in improving the measured productivity performance of the $\mathrm{U}$. S. manufacturing sector, I am unaware of any similar comments about the potential for noncomparability in retailing productivity.

\section{Economic Institutions and Culture}

A refreshing contrast is provided by Phelps (2003), who takes a broader view of 
economic institutions that promote economic "dynamism" and those that suppress it. His analysis of "dynamism" starts from Schumpeter's concept of "creative destruction". He adds to Schumpeter's emphasis on entrepreneurship an equal if not greater emphasis on "financiership," that is, the ability of financial markets to steer finance to worthy innovations. The greater success of the U.S. in encouraging innovation is attributed in part to its greater emphasis on venture capital and initial public equity offerings (IPO) than in Europe.

\section{Europe: Corporatism and Spoiled Youth}

In Phelps' view, the relatively poor economic performance of continental Europe results both from the underdevelopment of capitalist institutions like venture capital and equity finance, and the overdevelopment on corporatist institutions which suppress innovation and competition. These corporatist institutions impose "penalties, impediments, prohibitions, and mandates ... generally intended to damp down creative destruction." Among these impediments are licenses and permissions to set up a new plant or firm, the need to consult with workers on changes in the mix of products or plants, and employment protection legislation. Because these institutions are designed to suppress the changes inherent in "unbridled capitalism," they also lead to the underdevelopment of the stock market, resulting in lower ratios of stock market valuation to GDP in continental Europe than in the U. S. and other less corporatist economies like Britain, Canada, and 
Australia. Phelps provides a complementary analysis of cultural differences between Europe and the U.S. Europeans view with disdain the money-grubbing Americans with their out-sized rewards for CEOs and successful entrepreneurs. American children begin to work earlier than European children, earning baby-sitting money in their early teens, working in fast-food outlets while in high school, and are forced to work during college in contrast to European youth who "free ride" on government-paid college tuition and stipends. Phelps concludes that Europe has developed a culture of "dependency" that "breeds an unduly large share of young people who have little sense of independence and are unwilling to strike out on their own." He might have added that high levels of longterm youth unemployment discourage independence and encourage young adults to live with their parents in their 20s and, in Italy, into their 30s.

\section{Caveats}

Europeans do not take these criticisms lying down. Yes, they admit that high youth unemployment, low labor force participation, and a generation of young adults living with their parents represent an economic and social failure. But they are quick to criticize aspects of American economic and political institutions that, while making it easy for WalMart and Home Depot to find the land to build thousands of "big box" stores, has offsetting disadvantages.

Europeans find abhorrent the hundreds of billions, or even trillions, that Americans 
have spent on extra highways and extra energy to support the dispersion of the population into huge metropolitan areas spreading over hundreds or even thousands of square miles, in many cases with few transport options other than the automobile. Productivity data do not give Europe sufficient credit for the convenience benefits of frequent bus, subway, and train (including TGV) public transit. Excessive American dispersion is viewed as a response to misguided public policies, especially subsidies to interstate highways in vast amounts relative to public transport, local zoning measures in some suburbs that prohibit residential land allocations below a fixed size, e.g., two acres, and the infamous and politically untouchable deduction of mortgage interest payments from income tax.

Europeans enjoy shopping at small individually owned shops on lively central city main streets and pedestrian arcades, and recoil with distaste from the ubiquitous and cheerless American strip malls and big-box retailers - although Carrefour, Ikea, and others provide American-like options in some European cities. To counter the effects of American land use regulations that create overly dispersed metropolitan areas, Europeans counter with their own brand of land use rules that preserve greenbelts and inhibit growth of suburban and exurban retailing. A more complete consideration of these differences leads to the conclusion that GDP data understate the Europe/U. S. ratio of both productivity and real GDP per capita (see Gordon, 2002). 
Leaving the Station, Page 16

\section{Incentives for Innovation in the U. S. and Europe}

Thus far we have concluded that ICT investment has been exaggerated as the sole source of the U. S. productivity revival of the late 1990s, and it is even more clear that lack of ICT investment has been wrongly cited as the main source of the contrasting productivity performance in Europe. The main U. S. advantage was in retail and wholesale trade, where the expansion of new establishments raised productivity growth for many reasons going well beyond ICT investment, and the ability of Europe to expand in tandem was hampered by regulations and institutions that have long been cited as a drag on European economic growth.

Albeit narrowly based in computer hardware, at least in the official statistics, the apparent "rupture" or discontinuity in the rate of technical change in the mid-1990s forces to inquire as to its sources and lessons for understanding the economic history of the U.S. and other nations. America is now almost universally believed to have surged to the forefront in most of the ICT industries. But our overview of the stimuli and barriers to technological change and innovation focusses not just on computer hard ware more broadly on software, telecommunications, pharmaceuticals, and biotech. Why did the U. S. have a comparative or absolute advantage in innovative capacity in the late 1990s, more than a century after its initial leadership in the invention of electricity and its early lead in the 
exploitation of the internal combustion engine?

\section{National Technological Leadership: General Considerations}

The mid-1990s discontinuity of technical change in the United States was not predicted in advance, although its significance was spotted almost immediately by Business Week and some other astute observers. ${ }^{7}$ A decade earlier it had been "Japan as Number One", and briefly the market value of Japanese equities exceeded that of American equities. Rosenberg (1986, p. 25) perceptively generalizes about the difficulty of forecasting the consequences of inventions in advance: "A disinterested observer who happened to be passing by at Kitty Hawk on that fateful day in 1903 might surely be excused if he did not walk away with visions of 747s or C-5As in his head." The great success of Japanese firms in dominating many leading technologies in the 1980s did not appear to give them any head start in dominating the new technologies of the 1990s. Rosenberg points to the failure of carriage makers to play any role in the development of the automobile, or even the failure of steam locomotive makers to participate in the development of the diesel locomotive. Thus it is perhaps not surprising that Japanese electronics companies did not participate to any great extent in the particular interplay of chip-making technology and software development that created the Internet and the post-1995 technical acceleration in

\footnotetext{
7. Most notably Edward Yardeni, now the Chief Economist of Prudential Securities, who early in the 1990 s predicted both the stock market boom and the revival of productivity growth.
} 
computer hardware, although the Japanese more recently have been leaders in the development of mobile phones with cameras and internet capability.

Many inventions initially created to solve a narrow problem (for instance, the steam engine was initially invented to pump water out of flooded mines) turned out to have widespread further uses that were not initially foreseen. Major inventions spawn numerous complementary developments; while the initial motivation for the internal combustion engine was to improve the performance-to-weight ratio of the steam engine, it made possible not only motor transport and air transport, but such complementary developments as the suburb, supermarket, superhighway, and the tropical vacation industry. In turn, the complementary inventions raise the consumer surplus associated with the invention, and this may continue for a long time. The invention of the Internet is just one of many byproducts of the invention of electricity that raise the consumer surplus of that initial major invention. ${ }^{8}$

The literature on technology distinguishes between the initial invention and its subsequent development and diffusion. A longstanding puzzle in the retardation of British economic growth after the 1870s is the fact that many inventions initially made by British inventors were brought to commercial success in the U. S., Japan, and elsewhere. This 
issue of who captures the fruits of innovation suggests that the British were not alone in losing out. The U. S. invention of videotape was followed by exploitation of the consumer VCR market that was almost entirely achieved by Japanese companies. The Finnish company Nokia took over leadership in mobile phones from Motorola. Within any economy there are winners and losers as upstart companies (Intel, Microsoft) seize the advantage in developing technology while leaving older competitors (IBM, Wang, Digital Equipment, Xerox) behind.

While predicting technological developments in advance is exceedingly difficult, there is an ample literature which points to particular national characteristics that help to explain, at least in retrospect, why particular inventions and industries came to be dominated by particular countries. ${ }^{9}$ Perhaps the one generalization that spans most industries is the role of the product cycle. No matter what the causes of initial national leadership, technology eventually diffuses from the leading nations to other nations that may have lower labor costs. It is beyond the scope of this discussion to explain why some nations, e.g., Korea, Taiwan, and Singapore, seem to have done so much better than other nations, e.g., Brazil or Bangladesh, in combining technological duplication with an advantage, at least initially, in labor costs, in industries ranging from automobiles to chip,

\footnotetext{
9. The generalizations in the next several paragraphs select among the more important points made by Mowery and Nelson (1999a).
} 
computer, and disk-drive manufacturing.

\section{The Traditional Sources of U. S. Advantage.}

According to the standard data compiled by Maddison and others, summarized for Europe (but not individual countries) in Table 1 above, the level of output per hour in the United States moved ahead of that in the United Kingdom in the late nineteenth century and has remained in first place among the major developed nations ever since. An extensive literature on the sources of U.S. superiority (e.g., Wright, 1990) identifies national advantages both in the supply of resources and in national characteristics of demand. The U. S. achieved initial leadership in petrochemicals in part because of its abundant supply of cheap domestic petroleum, while its leadership in machine tools was the result of its early adoption of mass production methods, which in turn reflected its relative scarcity of labor and its large internal market. In turn mass production, together with long distances, cheap land, and the low density of urban development help to explain why the U. S. achieved such an enormous early lead in automobile production and ownership in the 1920s. In turn the mass market for automobiles fed back into a rapidly increasing demand for gasoline and stimulated further developments in petroleum and petrochemical manufacturing. The enormous American lead in its 1929 capacity to manufacture engines for motor vehicles, with perhaps 80 percent of worldwide capacity, contributed the core of the astounding production achievement of the 1942-45 "Arsenal of Democracy." 
However, it is less clear that America's large domestic market provided a universal source of advantage throughout the history of technological development over the last two centuries. Between 1870 and 1914 flows of goods, capital, and immigrants were notably free, and trade could create international markets on the scale of the U. S. domestic markets, as demonstrated by German dominance in chemicals. After 1960 Japan rose to prominence and even domination in one industry after another, with export markets providing the scale that was lacking, at least initially, at home. Several small countries, e.g., the Netherlands and Sweden, have remained close to the productivity frontier over the past century despite their small relative size.

\section{Educational Attainment and University Research.}

Close integration of industrial R\&D and university research is credited with German domination of the chemical products industry between the 1870s and early 1920s, as well as German and Swiss leadership in the development of pharmaceuticals in the early part of the 20th century. More generally, a rise in educational attainment is one of the sources of rising output per hour. While the first cited role of the education system in technological development is the rise of the German chemical industry after 1870, a set of relatively uncoordinated policies at the state and local level resulted in the U. S. achieving the first universal secondary education between 1910 and 1940 (Goldin, 1998) and the highest rate of participation in college education after World War II. 
Even in the dismal days of American pessimism during the years of the 1972-95 productivity slowdown, it was widely recognized that America's private and statesupported research universities were its most successful export industry, at least as measured by its lead over other countries and its appeal for students from the rest of the world. The interplay among these research universities, government research grants, and private industry was instrumental in achieving American leadership in the IT industry, and it was no coincidence that Silicon Valley happened to be located next to Stanford University or that another concentration of IT companies in the hardware, software, and biotech industries was located in the Boston area near M.I.T. and Harvard.

A U.S. educational advantage of possible importance is its early development of the graduate school of business and its continuing near-monopoly in this type of education. The mere existence of business schools did not provide any solution to the productivity slowdown of the 1970s and 1980s, and indeed the ongoing superiority of Japanese firms in automobiles and consumer electronics elicited the cynical joke in those years that "the secret advantage of the Japanese manufacturers is that they have no world-class business schools." While U. S. business schools were indeed weak in teaching such specialities as manufacturing production and quality control, they excelled in finance and general management strategy. These skills came into their own in the 1990s and interacted with the rise of the venture capital industry and internet start-up companies; in the United States 
more than elsewhere there was a ready supply of thousands of well-educated MBAs, both knowledgeable about finance and receptive to a culture of innovation and risk-taking. Further, U. S. business schools have provided a wealth of talent to further develop U. S. worldwide dominance in investment banking, accounting, and management-consulting firms.

\section{Government-funded Military and Civilian Research.}

Ironically for a country that has been suspicious of government involvement, it is the United States that appears to demonstrate the closest links between government policy and technological leadership. The central role of government subsidies in achieving economic growth in the United States go back to the last half of the nineteenth century, when free farmland under the Homestead Act encouraged immigration and the settlement of the frontier, while land grants to railroads promoted the building of infrastructure. Efficiency in the development of America's endowment of land and raw materials was fostered by agricultural experiment and research stations and by schools of mining established as part of America's then-new network of state universities and colleges (Wright, 1990). In the modern era research support from the National Institutes of Health and National Science Foundation are credited with postwar American leadership in pharmaceuticals and biomedical research, as well as basic research in the sciences. Defense-funded research and government-funded grants is credited with the early 
emergence of American leadership in semiconductors, computers, software, biotech, and the Internet itself. Government antitrust policy is credited with the emergence of a software industry largely independent of computer hardware manufacturers.

There are notable differences between the U. S. method of supporting higher education and research and that found in European countries like France, Germany, and the U. K. First, the U.S. mix of private universities and those financed at the state and local level promotes competition and allows the top tier of the private university sector the budgetary freedom to pay high salaries, fund opulent research labs, and achieve the highest levels of quality, in turn attracting many top faculty members and graduate students from other countries. Second, much of U.S. central government research support is allocated through a peer-review system that favors a meritocracy of young, active researchers and discourages elitism and continuing support for senior professors whose best ideas are in the past. In Europe a much larger share of central government support to universities and research institutes goes to general budgetary support that tends to result in a more equal salary structure less prone to reward academic "stars" and also relies less on the periodic quality hurdle imposed by peer review. This set of differences is in addition to specific national shortcomings, e.g., the hierarchical dominance of senior research professors in Germany.

\section{Other Government Policies.}


Explicit government policies to encourage the development of specific industries by trade protection and financial subsidies may have been successful in helping to accelerate the rise of Japan and Korea to industrial success, but they have been less successful in the United States and Europe and indeed may have backfired in Japan in the past decade. The relevance of particular government policies, from protection to defense spending to antitrust, differs sufficiently across industries as to discourage generalizations. In the industries that have received the most credit for the post-1995 productivity revival semiconductors, computer hardware, and computer software - the most important aspect of public policy appears to have been the relatively unfocussed support of research and training by the U. S. government. The literature on the American resurgence in semiconductor production as well as its continuing dominance in software also emphasizes the role of private enforcement of intellectual property rights and regulation of licensing agreements (see Bresnahan and Melerba, 1999, and Mowery, 1999). The U. S. pharmaceutical industry initially gained an advantage through massive government support during World War II, health-related research support during most of the postwar period, and a long tradition of strong U.S. patent protection - patent protection was also strong in parts of Europe, but not in Italy and also not in Japan. U. S. drug companies also were able to make high profits, much of which was reinvested in $R \& D$, as a result of high rents earned in the face of a fragmented health care system with no attempt by the 
government to place price or profit ceilings on drug companies (see Pisano 2002).

Another set of U.S. policies could be interpreted as "enforcement of benign neglect."

The U. S. government took no action to arrest the erosion of state sales tax revenues as internet e-commerce merchants sold items without charging any sales tax to customers. In effect, the freedom of e-commerce transactions from the burden of sales taxes amounted to government subsidization of shipping charges, since for e-commerce these usually amounted to roughly the same surcharge on listed prices as sales taxes at traditional bricks and mortar outlets. The U. S. government also maintained a zero-tariff regime for trade in electronic components, fostering large trade flows in both directions and a large U.S. trade deficit in IT manufacturing.

\section{Capital Markets}

In the 1980s American capital markets seemed to be a source of American industrial weakness, with their emphasis on short-run profit maximization, and there was much envy of the access of Japanese firms to low-cost bank capital that played a role in the temporary period of Japanese domination of the semiconductor industry. But the American capital market turned out to be a blessing in disguise. A long tradition of government securities regulation that forced public disclosure and information and of access of equity research analysts to internal company information had fostered a large and active market for public offerings, and this together with the relatively recent emergence of the venture capital 
industry provided ample finance for start-up companies once the technological ground work for the Internet was laid in the mid-1990s. ${ }^{10}$ Lerner (2002) identifies a critical policy change as fostering the relatively recent rise of the U. S. venture capital industry, namely a ruling that allowed pension funds to invest in venture capital firms. While the stock market collapse in 2000-02 brought the venture capital industry down with it, the financial infrastructure is still there seeking out the next round of innovation. Only a small part of this endowment of innovation-seeking financial specialists was lost during the 200002 stock market decline. Further, the next wave of equity financing will take place in an environment in which accounting scandals have been discovered, perpetrators have been tried and jailed, and public confidence in the integrity of financial statements has been substantially increased.

\section{Language and Immigration}

The literature on technological leadership omits two sources of American advantage that are surely not insignificant. While language has little to do with domination in computer hardware (where indeed many of the components are imported), it is surely important for the American software industry that English long ago became the world's

\footnotetext{
10. As usual there are interconnections between the various sources of American advantage. For instance, the best U. S. private universities have been a critical source of U. S. technological leadership and their wealth and power has been further augmented by their recent investments in U. S. venture capital firms. For instance in 1999 Harvard made roughly a 150 percent return on its venture capital investments and a return of over 40 percent on its entire endowment which now totals almost $\$ 20$ billion.
} 
leading second language in addition to being spoken as a first language by a critical mass of the world's educated population. Another oft-neglected factor that should be discussed more often is the longstanding openness of the United States to immigration and the role of immigrants from India, East Asia, and elsewhere in providing the skilled labor that has been essential to the rise of Silicon Valley. Likewise, Indians returning from Silicon Valley have taken the lead in developing India's capabilities in programming and call centers that have fueled the current American debate about the potential harm or benefit of "outsourcing."

Another aspect of American advantage and disadvantage is also perhaps too little discussed. The technology literature summarized above places heavy emphasis on the unique role of American research universities in providing a competitive atmosphere geared to the attraction of the best faculty performing the best research. Yet every year another set of test results is announced in which Americans score far down the league tables in math and science when compared to numerous countries in Europe and Asia. Those who wring their hands about the state of American elementary and secondary education might better spend their energies lobbying Congress to increase the immigration quotas for highly educated individuals with skills in those areas where some Americans are weak, especially science and engineering. And those who would argue that loosening of high-skilled quotas should occur at the cost of a reduction in low-skilled quotas are 
urged to consider the many benefits of immigration in general, including the provision of new workers to ease the strain of overly tight labor markets, the revitalization of many central cities, and the postponement forever of any so-called Social Security "crisis."11

\section{Comparisons with Other Countries}

In most comparisons among the leading industrialized nations Britain (and sometimes Canada) occupy a central ground between the extremes of American exceptionalism and the opposite tendencies of the continental Europeans and Japanese, whether concerning the level of unemployment, employment protection or the lack thereof, the degree of inequality, and the extent of government spending. Yet in comparing the extent of American technological leadership with other countries, the story is not one of extremes, and the balance of advantage varies widely by industry.

Americans dominate most strongly in microprocessors and in computer software. As documented by Langlois (2002), the extent of Intel's domination of the worldwide market for microprocessors is perhaps unprecedented in industrial history, and the same could be said for Microsoft. However, the U. S. advantage in computer hardware is qualified by the role of Asian countries in providing components like memory chips, hard drives, and laptop screens. In fact the United States runs a large trade deficit in computer

11. A detailed critique of the current immigration assumptions of the U. S. social security trustees is contained in Gordon (2003, pp. 264-9). 
hardware and peripherals, both because of component imports from Asia and because a substantial share of production by American companies like Intel and Dell takes place not just at home but also in foreign countries like Malaysia and Ireland. In mobile telephones the U. S. has been handicapped by regulation that favored too much competition and allowed multiple standards, thus allowing the dominant producers of GSM equipment and infrastructure (Nokia and Ericsson) to run away with the worldwide mobile phone market. The American pharmaceutical industry also faces strong competition from British, German, and Swiss firms, although recent evidence suggests that key research labs are moving from Europe to Boston, the Bay Area, and other U. S. research centers. ${ }^{12}$

Several sources of systemic U. S. advantage stand out, most notably the mixed system of government- and private-funded research universities, the large role of U.S. government agencies providing research funding based on a criterion of peer review, and the strong position in a worldwide perspective of U. S. business schools and U. S.-owned investment banking, accounting, and management-consulting firms. By comparison Germany seems particularly weak in its failure to reform its old-fashioned hierarchical university system, its bureaucratic rules that inhibit start-up firms, its reliance on bank debt finance, and its weakness in venture capital and equity finance (Siebert and Stolpe, 2002).

\footnotetext{
12. A meeting of the Governors for Health Care at the World Economic Forum in Davos, Switzerland, on January 22, 2004, centered on the current "brain drain" of pharmaceutical research from Europe to the U.S.
} 
France suffers from overcentralized government control, a system of universities and research institutions which places more emphasis on rewarding those with an elite educational pedigree rather than those currently working on the research frontier, and a culture (with its frequent strikes by farmers and government workers) which is relatively hostile to innovation and change (see Messerlin, 2002).

Until its structural reforms and privatizations of the 1980s and 1990s, Britain shared with France and Germany a labor market dominated by strong unions. While the strong unions are gone, Britain continues to suffer from handicaps that date back a century or more, including a shortfall of technical skills among manual workers and a lack of graduate management training and business-oriented culture among highly educated workers. Where Britain does well, as in investment banking or as a destination of inward foreign investment, it relies on a relatively narrow set of advantages, including the traditional role of the City of London as a financial center, and the same advantage that the English language provides, i.e., as a comfortable place for Asian firms to build plants, to the United States, Canada, Ireland, Australia, and other parts of the former British Empire.

\section{Conclusion}

After fifty years of catching up to the U. S. level of productivity, since 1995 Europe has been falling behind. The growth rate in output per hour over 1995-2003 in Europe was 
just half that in the United States, and this annual growth shortfall caused the level of European productivity to fall back from 94 percent of the U. S. level to 85 percent (Table 1 above). Fully one-fifth of the European catch-up (from 44 to 94 percent) over the previous half-century has been lost over the period since 1995.

Since Europe uses the same computer hardware and software as the U. S., the impediments to European growth must lie elsewhere than inadequate investment in ICT. The new upsurge of U. S. productivity growth during 2000-03, a period when ICT investment slumped, also suggests that ICT investment has previously been given too much credit for the U. S. productivity achievement, and insufficient attention has been directed to other contributing factors. References to "Europe" disguise a wide variety of performance, with Ireland and Finland exhibiting much faster productivity growth than the U. S., but "olive belt" nations like Italy and Greece scoring low on productivity and ICT investment (except for mobile phones). Disaggregated studies of industrial sectors suggest that the main difference between Europe and the U. S. is in ICT-using industries like wholesale and retail trade and in securities trading. The contrast in retailing calls attention to regulatory barriers and land-use regulations in Europe that inhibit the development of the "big box" retailing formats that have created many of the productivity gains in the U.S.

For many decades, the U. S. and Europe have gone in opposite directions in the public policies relevant for metropolitan growth. The U.S. has promoted highly dispersed 
low-density metropolitan areas through its policies of building intra-urban highways, starving public transit, tax subsidies to home ownership, and allowing local governments to maintain low density by maintaining minimum residential lot sizes. Europeans have chosen different policies, including public transit subsidies that seem lavish by American standards, with less generous tax subsidies to home ownership and land use policies which encourage high-density residential living and retail precincts in the central city while inhibiting the exploitation of "greenfield" suburban and exurban sites suitable for modern "big box" retail developments.

Phelps provides a unifying framework in which economic dynamism is promoted by policies that promote competition and flexible equity finance and is retarded by corporatist institutions which are designed to protect incumbent producers and inhibit new entry. He also points to European cultural attributes that inhibit the development of ambition and independence by teenagers and young adults, in contrast to their encouragement in the U.S. While competition, corporatism, and culture may help to explain the differing evolution of productivity growth on the two sides of the Atlantic since 1995, they reveal institutional flaws in both continents that are inbred and likely to persist.

The outstanding performance of American productivity growth since 1995 raises the danger of a resurgent American triumphalism, perhaps symbolized by an imaginary Arc 
de Triomphe erected over Sand Hill Road at the border between Palo Alto and Menlo Park, CA, the heart of Silicon Valley. No doubt the growing American dominance of innovation in ICT, biotech, and pharmaceuticals reflects in part the fruitful collaboration of government research funding, world-leading private universities, innovative private firms, and a dynamic capital market. However, we should be cautious. The favorable preconditions that fostered innovation after 1995 did not prevent the U. S. from experiencing the dismal 1972-95 years of the productivity growth slowdown and nearstagnation of real wages, and they do not give the U. S. an advantage in many other industries. A quarter century after the invasion of Japanese auto imports, the quality rankings of automobiles still are characterized by a bimodal distribution in which Japanese nameplates (even those manufactured in the U. S.) dominate the highest rankings and American nameplates dominate the lowest. ${ }^{13}$ The U. S. shows no sign of regaining leadership in the manufacturing of computer peripherals or machine tools. The U. S. innovation infrastructure remains fertile soil when the right seeds are planted, as after 1995, but fertile soil without the right seeds can lie fallow for decades.

13. See Consumer Reports, April, 2004, and the latest J. D. Powers initial quality rankings. 


\section{REFERENCES}

Bartlesman, Eric, Bassanini, Andrea, Haltiwanger, John, Jarmin, Ron, Scarpetta, Stefano, and Schank, Thorsten (2002). "The Spread of ICT and Productivity Growth: Is Europe Really Lagging Behind in the New Economy," OECD draft report presented at Conference "The Information Economy: Productivity Gains and the Digital Divide," Catania, Sicily, June 15.

Bresnahan, Timothy F., and Gordon, Robert J. (1997). "Introduction," The Economics of New Goods. University of Chicago Press for NBER, pp. 1-26.

and Malerba, Franco (1999). "Industrial Dynamics and the Evolution of Firms' and Nations' Competitive Capabilities in the World Computer Industry," in Mowery and Nelson, eds. (1999b), pp. 79-132.

Colecchia, Allessandra, and Schreyer, Paul (2001). "ICT Investment and Economic Growth in the 1990s: Is the United States a Unique Case?" OECD, Paris, draft paper, October 7.

Daveri, Francesco (2002). "The New Economy in Europe (1992-2001)," IGIER Working Paper no. 213, April.

Foster, Lucia, Haltiwanger, John, and Krizan, C. J. (2002). "The Link between Aggregate and Micro Productivity Growth: Evidence from Retail Trade," NBER Working Paper 9120, August.

Goldin, Claudia (1998). "America's Graduation from High School: The Evolution and Spread of Secondary Schooling in the Twentieth Century." Journal of Economic History, vol. 58 (June), pp. 345-74.

Gordon, Robert J. (2002). "Two Centuries of Economic Growth: Europe Chasing the American Frontier," working paper, Northwestern University, November. Available at http://faculty-web.at.northwestern.edu/economics/gordon

(2003). "Exploding Productivity Growth: Context, Causes, and Implications," Brookings Papers on Economic Activity, vol. 34, no. 2, pp. 207-98. 
Jorgenson, Dale W. and Stiroh, Kevin J. 2000. "Raising the Speed Limit: U. S. Economic Growth in the Information Age," Brookings Papers on Economic Activity, vol. 31, no. 1, pp. 125-211.

Langlois, Richard N. (2002). "Computers and Semiconductors," in Steil, Benn, et al., eds. (2002), pp. 265-84.

Lerner, Josh (2002). "Venture Capital," in Steil, Benn, et al., eds. (2002), pp. 327-46.

Maddison, Angus (2001). The World Economy: A Millennial Perspective. Paris: OECD.

Messerlin, Patrick A. (2002). "France", in Steil, Benn, et al., eds. (2002), pp. 148-77.

McGuckin, Robert H., and van Ark, Bart (2004). Performance 2003, Productivity, Employment and Income in the World's Economies. New York: The Conference Board, March.

McKinsey Global Institute (1992). Service Sector Productivity. Washington, October.

Mowery, David C. (1999). "The Computer Software Industry," in Mowery and Nelson, eds. (1999b), pp. 133-68.

and Nelson, Richard R. (1999). "Explaining Industrial Leadership," in Mowery and Nelson, eds. (1999b), pp. 359-82.

and Nelson, Richard R., eds. (1999b). Sources of Industrial Leadership: Studies of Seven Industries. Cambridge UK: Cambridge University Press.

and Rosenberg, Nathan (2000). "Twentieth-Century Technological Change," in Stanley L. Engerman and Robert E. Gallman, The Cambridge Economic History of the United States, Volume III, the Twentieth Century. Cambridge University Press, pp. 803-925.

Oliner, Stephen D., and Daniel E. Sichel (2000). "The Resurgence of Growth in the Late 1990s: Is Information Technology the Story?" Journal of Economic Perspectives, vol. 14, Fall, pp. 3-22. 
Where Are We Going?" Economic Review, Federal Reserve Bank of Atlanta (third quarter), pp. 15-44.

O'Mahony, Mary, and van Ark, Bart (2003). EU Productivity and Competitiveness: An Industry Perspective: Can Europe Resume the Catching-up Process? DG Enterprise, European Union, Luxembourg. Downloadable from http://www.ggdc.net/pub/EU_productivity_and_competitiveness.pdf.

Phelps, Edmund S. (2003). "Economic Underperformance in Continental Europe: A Prospering Economy Runs on the Dynamism from its Economic Institutions," lecture, Royal Institute for International Affairs, London, March 18.

Pisano, Gary P. (2002). "Pharmaceutical Biotechnology," in Steil, Benn, et al., eds. (2002), pp. 347-66.

Rhine-Westphalia Institute for Economic Research (RWI) (2002). New Economy: An Assessment from a German Viewpoint. Essen, February.

Rosenberg, Nathan (1986). "The Impact of Technological Innovation: A Historical View," in Ralph Landau and Nathan Rosenberg, eds., The Positive Sum Strategy: Harnessing Technology for Economic Growth. Washington DC: National Academy Press, pp. 1732.

Siebert, Horst, and Stope, Michael (2002). "Germany," in Steil, Benn, et al., eds. (2002), pp. $112-47$.

Sieling, Mark, Friedman, Brian, and Dumas, Mark (2001). "Labor Productivity in the Retail Trade Industry, 1987-99," Monthly Labor Review (December), pp. 3-14.

Stiel, Benn, Victor, David G., and Nelson, Richard R. (2002). Technological Innovation and Economic Performance. Princeton and Oxford: Princeton University Press.

van Ark, Bart, Inklaar, Robert, and McGuckin, Robert H. (2003). "Changing Gear: Productivity, ICT and Service Industries in Europe and the United States," in J. F. Christensen and P. Maskell, eds., The Industrial Dynamics of the New Digital Economy. Edward Elgar, pp. 56-99. 
Leaving the Station, Page 38

Vijselaar, Focco, and Albers, Ronald (2002). "New Technologies and Productivity Growth in the Euro Area," European Central Bank Working Paper no. 122, February.

Wright, Gavin (1990). "The Origins of American Industrial Success: 1879-1940," American Economic Review, vol. 80 (September), pp. 651-68. 


\begin{tabular}{|c|c|c|c|c|c|}
\hline & Growth & $\begin{array}{l}\text { ate and L } \\
\text { U. S. vs. }\end{array}$ & $\begin{array}{l}\text { TABLE } 1 \\
\text { vel of GDP } \\
\text { Europe, } 18\end{array}$ & $\begin{array}{l}\text { Hour W } \\
003\end{array}$ & \\
\hline & Annual A & erage Gro & vth Rate & Europe & U. S. $=100$ \\
\hline & U. S. & Europe & $\begin{array}{l}\text { U. S. - } \\
\text { Europe }\end{array}$ & & \\
\hline & & & & 1870 & 71 \\
\hline $1870-1913$ & 1.92 & 1.55 & 0.37 & 1913 & 61 \\
\hline 1913-1950 & 2.48 & 1.56 & 0.92 & 1950 & 44 \\
\hline $1950-1973$ & 2.77 & 4.77 & -2.00 & 1973 & 79 \\
\hline 1973-1995 & 1.48 & 2.25 & -0.77 & 1995 & 94 \\
\hline $1995-2003$ & 2.33 & 1.15 & 1.18 & 2003 & 85 \\
\hline
\end{tabular}

Source: 1870-1990, Maddison (2001, Tables E-8 and E-9, pp. 352-3) 1990-2003, OECD Economic Outlook, December 2003, Table 13 


\begin{tabular}{|c|c|c|c|c|c|c|}
\hline \multicolumn{7}{|c|}{$\begin{array}{c}\text { Annual Rate of Change of Output, Hours, and Output per Hour, } \\
\text { U. S. vs. Europe, 1990-2003 }\end{array}$} \\
\hline & $1990-95$ & $1995-2000$ & $2000-03$ & & 1995-2003 & $\begin{array}{l}1995-2003 \\
\text { vs. } 1990-95\end{array}$ \\
\hline \multicolumn{7}{|l|}{ United States } \\
\hline Output & 2.4 & 4.1 & & 2.0 & 3.3 & 0.9 \\
\hline Hours & 1.4 & 2.2 & & 0.1 & 1.4 & 0.0 \\
\hline Output per Hour & 1.0 & 1.9 & & 1.9 & 1.9 & 0.9 \\
\hline \multicolumn{7}{|l|}{ European Union } \\
\hline Output & 1.5 & 2.6 & & 1.2 & 2.1 & 0.6 \\
\hline Hours & -1.0 & 1.1 & & 0.3 & 0.8 & 1.8 \\
\hline Output per Hour & 2.5 & 1.5 & & 0.9 & 1.3 & -1.2 \\
\hline
\end{tabular}

Source: McGuckin-van Ark (2004, Table 1). 


\begin{tabular}{|c|c|c|c|c|c|c|}
\hline \multicolumn{7}{|c|}{$\begin{array}{l}\text { Labor Productivity by Industry Group, U. S. vs. Europe, } \\
1990-95 \text { vs. 1995-2001, Annual Growth Rates in Percent }\end{array}$} \\
\hline & \multicolumn{3}{|c|}{ United States } & \multicolumn{3}{|c|}{ European Union } \\
\hline & $\begin{array}{l}1990- \\
1995 \\
\end{array}$ & $\begin{array}{l}1995- \\
2001 \\
\end{array}$ & $\begin{array}{l}1990- \\
2001 \\
\end{array}$ & $\begin{array}{l}1990- \\
1995 \\
\end{array}$ & $\begin{array}{l}1995- \\
2001\end{array}$ & $\begin{array}{l}1990- \\
2001\end{array}$ \\
\hline Total Economy & 1.1 & 2.2 & 1.6 & 2.3 & 1.7 & 2.0 \\
\hline ICT Producing Industries & 8.1 & 10.0 & 8.7 & 5.9 & 7.5 & 6.5 \\
\hline ICT Using Industries & 1.2 & 4.7 & 2.9 & 2.0 & 1.9 & 1.9 \\
\hline Non-ICT Industries & 0.3 & -0.2 & 0.0 & 1.2 & 0.5 & 0.8 \\
\hline
\end{tabular}

Source: O'Mahony and van Ark (2003, Table III.3). 